\title{
Antineoplastic activity of novel thiazole derivatives
}

\author{
N. S. Finiuk ${ }^{1,2}$, V. P. Hreniuh ${ }^{2}$, Yu. V. Ostapiuk ${ }^{3}$, V. S. Matiychuk 3 , D. A. Frolov², \\ M. D. Obushak ${ }^{3}$, R. S. Stoika ${ }^{1}$, A. M. Babsky ${ }^{2}$ \\ ${ }^{1}$ Institute of Cell Biology, NAS of Ukraine \\ 14/16, Drahomanov Str., Lviv, Ukraine, 79005 \\ ${ }^{2}$ Biology Faculty, Ivan Franko National University of Lviv \\ 4, Hrushevskoho Str., Lviv, Ukraine, 79005 \\ ${ }^{3}$ Chemistry Faculty, Ivan Franko National University of Lviv \\ 6, Kyrylo and Mefodiy Str., Lviv, Ukraine, 79005 \\ andriy.babsky@lnu.edu.ua
}

\begin{abstract}
The development of novel efficient substances for anticancer chemotherapy is an important problem of medicinal chemistry. Aim. To evaluate the level of cytotoxic action of novel thiazole derivatives towards tumor cell lines of different origin. Methods. Four N acylated 2-amino-5-benzyl-1,3-thiazoles (5a-d) were synthesized by reaction of 2-amino-5-R-benzyl-1,3-thiazoles with acid chlorides in the presence of triethylamine in the dioxane medium. Anticancer screening of the synthesized thiazoles was performed by the MTT assay. Results. Thiazole derivatives were shown to exert antineoplastic activity towards different types of tumor cells. The anti-glioma and anti-melanoma selectivity of these derivatives action was demonstrated. The compound $\mathbf{5 a}$ was found to be the most toxic for human glioblastoma U251 cells and human melanoma WM793 cells. At the same time, the created compounds possessed low toxicity towards pseudo-normal cells. Conclusion. The novel thiazole derivative 5a was the most toxic against human glioblastoma and melanoma cells.
\end{abstract}

Ke y w o r d s: thiazole derivatives, 2-amino-5-benzyl-1,3-thiazoles, anticancer activity, leukemia, glioblastoma, melanoma.

\section{Introduction}

The discovery and development of the conventional anticancer drugs have been mainly focused on the cytotoxic agents [1]. The perspective antineoplastic agents are expected to inhibit, delay or reverse the progression of cancer development through their cytotoxicity or apoptosis-inducing properties [2]. Cytotoxic drugs prevent the rapid growth and division (mitosis) of tumor cells [1]. However, many anticancer drugs do not possess enough selectivity towards their targets. Thus, their application for cancer treatment is associated with

(C) 2017 N. S. Finiuk et al.; Published by the Institute of Molecular Biology and Genetics, NAS of Ukraine on behalf of Biopolymers and Cell. This is an Open Access article distributed under the terms of the Creative Commons Attribution License (http://creativecommons.org/licenses/by/4.0/), which permits unrestricted reuse, distribution, and reproduction in any medium, provided the original work is properly cited 
numerous negative side effects in the organism $[3,4]$. Drugs demonstrate cytotoxicity toward different normal cells and organs, including bone marrow cells, reproductive glands, mucous layer of the intestine and hair follicles. These effects limit significantly application of some drugs and lead to the development of novel drugs.

Thiazole derivatives have attracted the interest of medicinal chemists due to a variety of their biological activities including antibacterial, anti-fungal, anti-HIV, anti-hypertension, anti-inflammatory, anti-cancer, anti-con- vulsive and anti-depressant [5-10]. The mechanisms of 1,3-thiazole derivatives antitumor activity may be associated with DNA intercalation [11, 12], PRL-3, SHP-2 and JSP-1 inhibition [13-16], tumor necrosis factor (TNF $\alpha)$ [17], anti-apoptotic bio-complex BclXL-BH3 [18], integrin avb3 [19], others. Thiazole ring belongs to the privileged scaffolds in modern medicinal chemistry $[11,20$, $21]$, particularly at discovering new anticancer agents.

Herein, we described novel $\mathrm{N}$-acylated 2-amino-5-benzyl-1,3-thiazoles and discovered<smiles>[R]c1ccccc1[N-]Cl</smiles>

$1 a-d$

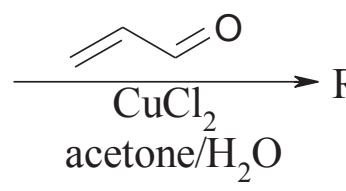
acetone $/ \mathrm{H}_{2} \mathrm{O}$<smiles>[R]c1ccc(CC(Cl)C=O)cc1</smiles>

2a-d<smiles>[R]c1cccc(Cc2cnc(N)s2)c1</smiles>

3a-d

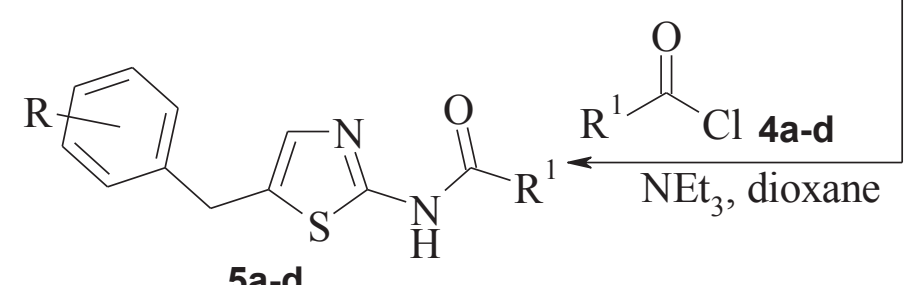

5a-d

1, 2, 3: $\mathrm{R}=\mathrm{H}(\mathbf{a}), 4-\mathrm{Et}(\mathbf{b}), 4-\mathrm{Br}(\mathbf{c}), 3,4-\mathrm{Cl}_{2}(\mathbf{d})$

Entry

Fig. 1. General scheme of synthesis of thiazole derivatives 
anticancer activity of the obtained amides. The synthesis of the target acylated 5-R-benzyl1,3-thiazol-2-amines 5 is presented in Fig. 1 . At the first step, the acrolein reacts with arenediazonium salts $(1 \mathrm{a}-\mathrm{d})$ in the presence of copper(II) chloride under the Meerwein arylation conditions. 3-Aryl-2-chloropropanals $(2 \mathrm{a}-\mathrm{d})$ react with the thiourea in ethanol at refluxing and form 2-amino-5-R-benzyl-1,3thiazoles $(3 \mathrm{a}-\mathrm{d})$ with good yield $[22,23]$. Previously, we have discussed the synthetic possibilities of 5-benzyl-2-aminothiazoles during the synthesis of 2-[(5-benzyl-1,3-thiazol2-yl)imino]-1,3-thiazolidin-4-ones as potential biologically active compounds [24, 25]. In this paper, we described $\mathrm{N}$-acylated 2-amino5-benzyl-1,3-thiazoles $(5 \mathrm{a}-\mathrm{d})$ obtained by the reaction of 2-amino-5-R-benzyl-1,3-thiazoles $3 \mathrm{a}-\mathrm{d}$ with acid chlorides $4 \mathrm{a}-\mathrm{d}$ in the presence of trietylamine in the dioxane medium.

The present study was addressed on the synthesis of thiazole derivatives containing some heterocyclic cores and the evaluation of their anticancer activity towards tumor cell lines of different tissue origin.

\section{Materials and Methods}

\section{Thiazole derivatives}

A $10 \mathrm{mM}$ stock solution of thiazole derivatives was prepared in the dimethyl sulfoxide (DMSO, Sigma-Aldrich, USA), and additionally dissolved in a culture medium prior to addition to the cell culture.

General Procedure for the Synthesis of 3-aryl-2-chloropropanales 2a-d [23]

A three-necked flask equipped with a dropping funnel, a stirrer, and a gas-outlet tube attached to a bubble counter was charged with acrolein (0.2 mol or $\left.13.5 \mathrm{~cm}^{3}\right), \mathrm{CuCl}_{2} \cdot 2 \mathrm{H}_{2} \mathrm{O}(10 \mathrm{~g})$, and acetone $\left(50 \mathrm{~cm}^{3}\right)$. Then, cold aqueous solution of arenediazonium chloride $1 \mathrm{a}-\mathrm{d}$ prepared by diazotization of aniline $(0.2 \mathrm{~mol})$ was added drop-wise to the flask under vigorous stirring. The temperature of the mixture was kept within $10-30^{\circ} \mathrm{C}$. The organic phase was separated when the reaction was completed, and the aqueous phase was extracted with chloroform. The extract was combined with the previous organic phase, dried over magnesium sulfate, evaporated, and the residue was distilled under reduced pressure.

General Procedure for the Synthesis of 2-amino-5-arylmethylthiazoles $3 a-d$

A mixture of $8 \mathrm{~g}$ of thiourea and $0.1 \mathrm{~mol}$ of 3-aryl-2-chloropropanal $2 \mathrm{a}-\mathrm{d}$ in $50 \mathrm{~cm}^{3}$ of ethanol was heated for $2 \mathrm{~h}$ under reflux. Then, it was cooled, diluted with $300 \mathrm{~cm}^{3}$ of water, and alkaline $\mathrm{pH}(\sim 9)$ was achieved by adding aqueous ammonia. The precipitate was filtered off and recrystallized from carbon tetrachloride. 5-Benzyl-1,3-thiazol-2-amine 3a has been described earlier [22, 23].

5-(4-Ethylbenzyl)-1,3-thiazol-2-amine 3b. Yield $86 \%$. M.p. $105-106{ }^{\circ} \mathrm{C} .{ }^{1} \mathrm{H}$ NMR (400 MHz, DMSO-d 6 ), $\delta: 7.11(\mathrm{~d}, J=7.8 \mathrm{~Hz}$, 2H), 7.08 (d, $J=7.8 \mathrm{~Hz}, 2 \mathrm{H}), 6.64(\mathrm{~s}, 1 \mathrm{H})$, $6.60(\mathrm{~s}, 2 \mathrm{H}), 3.81(\mathrm{~s}, 2 \mathrm{H}), 2.58(\mathrm{q}, J=7.7 \mathrm{~Hz}$, $2 \mathrm{H}), 1.19$ (t, $J=7.6 \mathrm{~Hz}, 3 \mathrm{H})$. Calculated, \%: C 66.02, H 6.46, N 12.83. $\mathrm{C}_{12} \mathrm{H}_{14} \mathrm{~N}_{2} \mathrm{~S}$. Found: C 65.85, H 6.33, N 12.58 .

5-(4-Bromobenzyl)-1,3-thiazol-2-amine 3c. Yield 84 \%. M.p. $123-125{ }^{\circ} \mathrm{C}$. ${ }^{1} \mathrm{H}$ NMR (400 MHz, DMSO-d 6 ), $\delta: 7.42(\mathrm{~d}, 2 \mathrm{H}, J=$ $8.1 \mathrm{~Hz}), 7.15(\mathrm{~d}, 2 \mathrm{H}, J=8.1 \mathrm{~Hz}), 6.61(\mathrm{~s}, 2 \mathrm{H})$, $6.64(\mathrm{~s}, 1 \mathrm{H}), 3.86(\mathrm{~s}, 2 \mathrm{H})$. Calculated, \%: 
44.62, H 3.37, N 10.41. $\mathrm{C}_{10} \mathrm{H}_{9} \mathrm{BrN}_{2} \mathrm{~S}$. Found: C 44.34, H 3.32, N 10.25 .

5-(3,4-Dichlorobenzyl)-1,3-thiazol-2-amine $3 d$. Yield $83 \%$. M.p. $92-94^{\circ} \mathrm{C} .{ }^{1} \mathrm{H}$ NMR $\left(400 \mathrm{MHz}, \mathrm{DMSO}-\mathrm{d}_{6}\right), \delta: 7.47(\mathrm{~d}, 1 \mathrm{H}$, $\mathrm{J}=8.4 \mathrm{~Hz}), 7.40(\mathrm{~d}, 1 \mathrm{H}, \mathrm{J}=1.8 \mathrm{~Hz}), 7.17(\mathrm{dd}$, $1 \mathrm{H},{ }^{4} \mathrm{~J}=1.8 \mathrm{~Hz},{ }^{3} \mathrm{~J}=8.4 \mathrm{~Hz}$ ), 6.67 (br. s, $3 \mathrm{H}$ ), 3.90 (s, 2H). Calculated, \%: C 46.35, H 3.11, $\mathrm{N}$ 10.81. $\mathrm{C}_{10} \mathrm{H}_{8} \mathrm{Cl}_{2} \mathrm{~N}_{2} \mathrm{~S}$. Found: $\mathrm{C} 46.22$, H 3.08, N 10.69 .

General Procedure for the Synthesis of compounds $5 a-d$

$5 \mathrm{mmol}$ of 2-amino-5-arylmethylthiazole $3 \mathrm{a}-\mathrm{d}$ was dissolved in the mixture of $5 \mathrm{ml}$ dioxane and $5 \mathrm{mmol}$ triethylamine. Solution of $5 \mathrm{mmol}$ acid chloride $4 \mathrm{a}-\mathrm{d}$ in $3 \mathrm{ml}$ dioxane was added drop-wise to the reaction mixture under vigorous stirring. Mixture was stirred for $2 \mathrm{~h}$, and diluted with $50 \mathrm{~cm}^{3}$ of water. The precipitate was filtered off and recrystallized from mixture EtOH/DMF.

$N$-(5-Benzyl-1,3-thiazol-2-yl)-3,5-dimethyl1-benzofuran-2-carboxamide $5 a$. Yield $75 \%$. M.p. $198{ }^{\circ} \mathrm{C} .{ }^{1} \mathrm{H}$ NMR $\left(400 \mathrm{MHz}, \mathrm{DMSO}-\mathrm{d}_{6}\right)$, $\delta: 12.42(\mathrm{~s}, 1 \mathrm{H}), 7.54(\mathrm{~s}, 1 \mathrm{H}), 7.49(\mathrm{~d}, 1 \mathrm{H}, J=$ $8.5 \mathrm{~Hz},), 7.35-7.26(\mathrm{~m}, 6 \mathrm{H}), 7.25-7.21(\mathrm{~m}$, $1 \mathrm{H}), 4.10$ (s, 2H), 2.54 (s, 3H), 2.42 (s, 3H). ${ }^{13} \mathrm{C}$ NMR (100 MHz, DMSO-d 6 ), $\delta: 152.10$, $142.44,140.64,133.87,133.04,131.92$, $131.80,129.66,129.55,129.07,129.01$, $128.89,126.98,124.10,121.23,111.93,32.54$, 21.36, 9.39. Calculated, \%: C, 69.59; H, 5.01; $\mathrm{N}$, 7.73. $\mathrm{C}_{21} \mathrm{H}_{18} \mathrm{~N}_{2} \mathrm{O}_{2} \mathrm{~S}$. Found: C, 69.29; $\mathrm{H}$, $4.94 ; \mathrm{N}, 7.63$.

$N$-[5-(4-Ethylbenzyl)-1,3-thiazol-2-yl]-1oxo-1H-isothiochromene-3-carboxamide $5 b$. Yield 83 \%. M.p. $190{ }^{\circ} \mathrm{C} .{ }^{1} \mathrm{H}$ NMR $(400 \mathrm{MHz}$, DMSO-d $\left._{6}\right), \delta: 13.09(\mathrm{~s}, 1 \mathrm{H}), 8.36(\mathrm{~s}, 1 \mathrm{H}), 8.18$ (d, 1H, $J=7.9 \mathrm{~Hz}), 7.99-7.88(\mathrm{~m}, 2 \mathrm{H}), 7.77$ (t, $1 \mathrm{H}, J=7.1 \mathrm{~Hz}), 7.33(\mathrm{~s}, 1 \mathrm{H}), 7.19(\mathrm{~d}, 2 \mathrm{H}$, $J=7.7 \mathrm{~Hz}), 7.16(\mathrm{~d}, 2 \mathrm{H}, J=8.1 \mathrm{~Hz}), 4.02(\mathrm{~s}$, $2 \mathrm{H}), 2.56(\mathrm{q}, 2 \mathrm{H} J=7.7 \mathrm{~Hz}), 1.15(\mathrm{t}, 3 \mathrm{H}, J=$ $7.5 \mathrm{~Hz}) \cdot{ }^{13} \mathrm{C}$ NMR $\left(101 \mathrm{MHz}, \mathrm{DMSO}-\mathrm{d}_{6}\right), \delta:=$ $187.30,156.46,155.32,146.97,142.55$, $137.57,136.91,135.26,132.92,131.54$, $129.01,128.86,128.77,128.55,128.48$, 128.46, 125.67, 32.43, 28.26, 16.11. Calculated, \%: C, 65.00; H, 4.46; N, 6.89. $\mathrm{C}_{22} \mathrm{H}_{18} \mathrm{~N}_{2} \mathrm{O}_{2} \mathrm{~S}_{2}$. Found: C, 64.57; H, 4.39; N, 6.75.

$\mathrm{N}$-[5-(4-Bromobenzyl)-1,3-thiazol-2-yl]-2(2,4-dimethylphenoxy)acetamide 5c. Yield $80 \%$. M.p. $150^{\circ} \mathrm{C}$. ${ }^{1} \mathrm{H}$ NMR $(400 \mathrm{MHz}$, DMSO- $\left._{6}\right), \delta: 12.15(\mathrm{~s}, 1 \mathrm{H}), 7.49(\mathrm{~d}, 2 \mathrm{H}, J=$ $8.2 \mathrm{~Hz}), 7.26(\mathrm{~s}, 1 \mathrm{H}), 7.21(\mathrm{~d}, 2 \mathrm{H}, J=8.2 \mathrm{~Hz})$, $6.95(\mathrm{~s}, 1 \mathrm{H}), 6.89(\mathrm{~d}, 1 \mathrm{H}, J=8.2 \mathrm{~Hz}), 6.66(\mathrm{~d}$, $1 \mathrm{H}, J=8.2 \mathrm{~Hz}), 4.77(\mathrm{~s}, 2 \mathrm{H}), 4.06(\mathrm{~s}, 2 \mathrm{H})$, $2.17(\mathrm{~s}, 3 \mathrm{H}), 2.16(\mathrm{~s}, 3 \mathrm{H}) \cdot{ }^{13} \mathrm{C}$ NMR $(101 \mathrm{MHz}$, DMSO- $\left.\mathrm{d}_{6}\right), \delta: 162.19,162.12,154.31,140.20$, $135.40,131.90,131.82,131.47,131.09$, 130.06, 127.46, 126.33, 120.03, 111.72, 66.91, 31.65, 20.52, 16.48. Calculated, \%: C, 55.69; $\mathrm{H}, 4.44 ; \mathrm{N}, 6.49 . \mathrm{C}_{20} \mathrm{H}_{19} \mathrm{BrN}_{2} \mathrm{O}_{2} \mathrm{~S}$. Found: $\mathrm{C}$, 55.32; H, 4.39; N, 6.33.

$N$-[5-(3,4-Dichlorobenzyl)-1,3-thiazol-2yl]-2H-chromene-2-carboxamide 5d. Yield $85 \%$. M.p. $216^{\circ} \mathrm{C}$. ${ }^{1} \mathrm{H}$ NMR $(400 \mathrm{MHz}$, DMSO-d $\left._{6}\right), \delta: 12.32(\mathrm{~s}, 1 \mathrm{H}), 7.69(\mathrm{~s}, 1 \mathrm{H}), 7.57$ (d, 2H, $J=8.3 \mathrm{~Hz}), 7.33$ (s, 1H), 7.31-7.22 (m, 3H), 6.99-6.95 (m, 1H), $6.86(\mathrm{~d}, 1 \mathrm{H}, J=$ $8.0 \mathrm{~Hz}), 4.98(\mathrm{~s}, 2 \mathrm{H}), 4.12(\mathrm{~s}, 2 \mathrm{H}) .{ }^{13} \mathrm{C} \mathrm{NMR}$ $\left(101 \mathrm{MHz}, \mathrm{DMSO}-\mathrm{d}_{6}\right), \delta:=154.88,142.01$, $132.33,132.22,131.50,131.47,131.19$, $131.14,130.84,130.76,129.58,129.50$, $129.46,129.33,129.27,122.44,121.38$, 116.28, 64.44, 31.21. Calculated, \%: C, 57.56; $\mathrm{H}, 3.38 ; \mathrm{N}, 6.71 . \mathrm{C}_{20} \mathrm{H}_{14} \mathrm{Cl}_{2} \mathrm{~N}_{2} \mathrm{O}_{2}$ S. Found: $\mathrm{C}$, $57.30 ; \mathrm{H}, 3.31 ; \mathrm{N}, 6.62$. 


\section{Cell culture}

Human breast adenocarcinoma cells of MCF7 line, lung adenocarcinoma cells of A549 line, glioblastoma cells of U251 line, myeloid leukemia cells of K562 line, acute T-cell leukemia cells of Jurkat line, and embryonic kidney cells of HEK293 line were obtained from Cell Collection of R.E. Kavetsky Institute of Experimental Pathology, Oncology and Radiology (Kyiv, Ukraine). Human melanoma cells of WM793 line were provided by Dr. O. Stasyk (Institute of Cell Biology, National Academy of Sciences of Ukraine, Lviv, Ukraine). Cells were grown in the RPMI (APP, Austria) or DMEM (Sigma-Aldrich, USA) culture medium supplemented with $10 \%$ fetal bovine serum (FBS, APP, Austria). Cells were cultivated in the $\mathrm{CO}_{2}$-thermostate at $37^{\circ} \mathrm{C}$ in atmosphere of $95 \%$ air and $5 \% \mathrm{CO}_{2}$.

\section{Cell proliferation assay}

Antineoplastic activity of the synthesized compounds towards cancer cell lines was measured by the MTT (3-(4,5-Dimethylthiazole2-yl)-2,5-diphenyl-tetrazolium bromide) test (Sigma-Aldrich, USA) [26]. The antitumor drug doxorubicin (Pharmachemie B.V., the Netherlands) was used as a reference drug control. Tumor cells were seeded for $24 \mathrm{~h}$ in 96-well plates in $100 \mu \mathrm{l}$ at the concentration of 5,000 cells/well (substrate-dependent cells) or 10,000 cells/well (suspension cells). After that, cells were incubated for next $72 \mathrm{~h}$ with various additions of the synthesized compounds or doxorubicin $(0-100 \mu \mathrm{M})$. MTT was added to the cells according to the manufacturer's protocol (Sigma-Aldrich, USA). The results of the reaction were determined by an Absorbance Reader BioTek ELx800 (BioTek
Instruments, Inc., USA). The $\mathrm{IC}_{50}$ of tested compounds was calculated as a lethal concentration of drug killing $50 \%$ of the cells in comparison with an untreated culture.

\section{Statistical analysis}

All data are presented as the mean \pm standard deviation. The results were analyzed and illustrated with GraphPad Prism (version 6; GraphPad Software, USA). Statistical analysis was performed using two-way ANOVA tests. $P$-value of $<0.05$ was considered as statistically significant.

\section{Results}

The synthesis of different derivatives of 2-amino-5-arylmethylthiazoles is described in the Materials and Methods section. The compounds under study were added to the cultured human tumor and pseudo-normal cells in different final concentrations $(0 ; 1$; $10 ; 50 \mu \mathrm{M}$ ) for $72 \mathrm{~h}$. Doxorubicin was used as a reference positive control. The obtained results were expressed as $\mathrm{IC}_{50}$ and presented in Figures 2-4. The synthesized thiazoles were shown to possess diverse anti-proliferative action towards tumor cells of different tissue origin.

In the first set of experiments, the anticancer effect of compounds was studied towards adenocarcinoma cells, namely human breast adenocarcinoma cells of MCF-7 line and human lung adenocarcinoma cells of A549 line. Doxorubicin demonstrated a much stronger cytotoxicity for MCF-7 cells comparing to the A549 cells (Fig. 2). However, both cell lines were relatively not sensitive to the action of studied thiazoles used in doses up to $50 \mu \mathrm{M}$. 

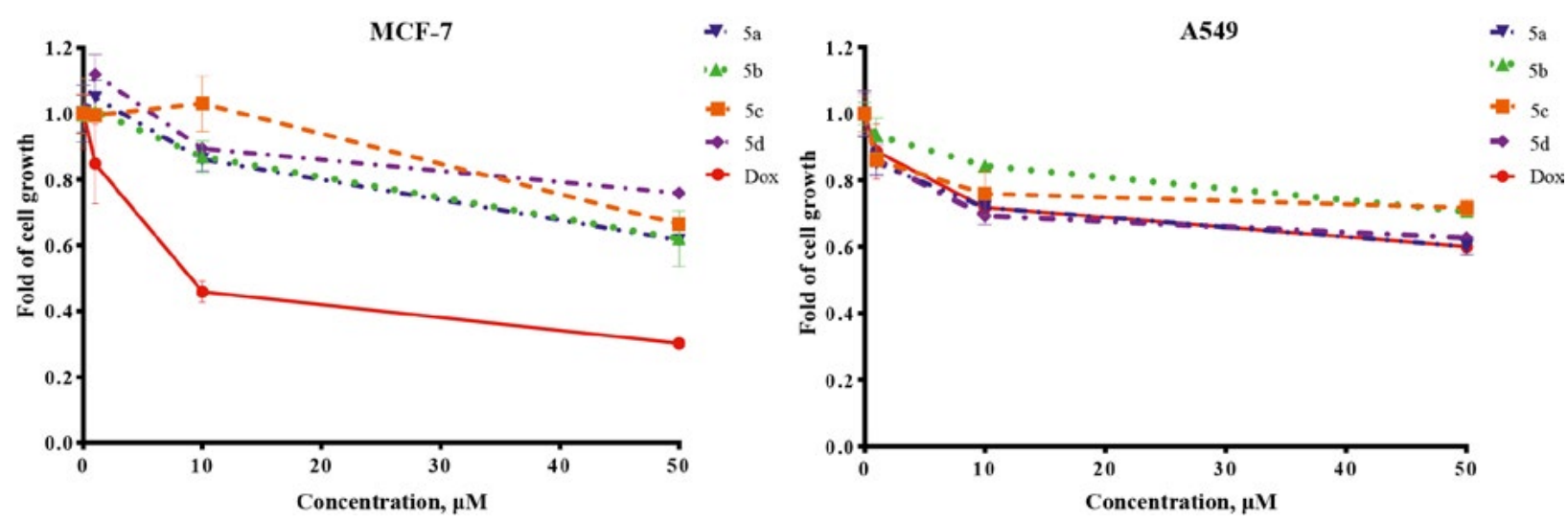

Fig. 2. Characteristics of cytotoxicity of thiazole derivatives (5a-d) and doxorubicin (Dox) towards human breast adenocarcinoma MCF-7 cells and human lung adenocarcinoma A549 cells.

The antineoplastic effect of the thiazole derivatives was also studied using human glioblastoma cells of U251 line and human melanoma cells of WM793 line. The concentrationdependent cytotoxicity effect of the thiazoles was found when the glioblastoma cells were treated. The synthesized $5 \mathrm{c}, 5 \mathrm{~d}$ and $5 \mathrm{~b}$ displayed a weak activity towards glioblastoma $\mathrm{U} 251$ cells $\left(\mathrm{IC}_{50}\right.$ for $5 \mathrm{c}$ was $40.0 \pm 2.46 \mu \mathrm{M}$; $\mathrm{IC}_{50}$ for $5 \mathrm{~d}$ was $36.5 \pm 1.96 \mu \mathrm{M}$ and $\mathrm{IC}_{50}$ for $5 \mathrm{~b}$ was $40.0 \pm 2.82 \mu \mathrm{M}$ ), and demonstrated cytotoxicity only when used in high dose $(50 \mu \mathrm{M})$.

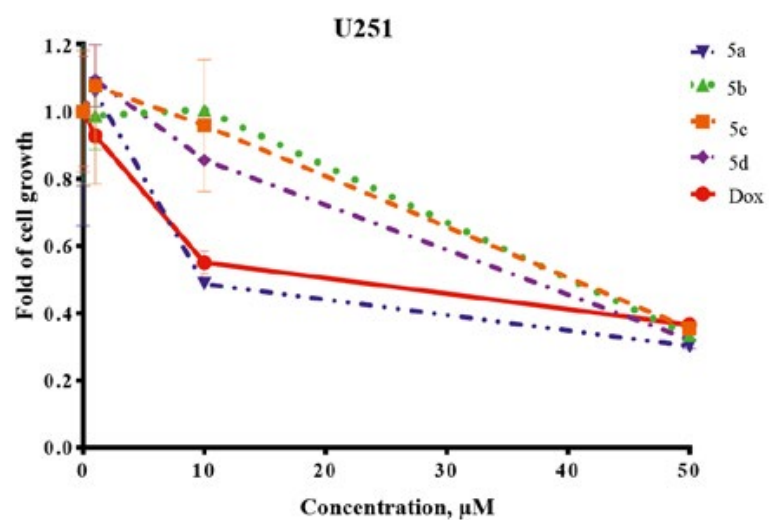

At the same time, the 5a compound was highly toxic for the glioblastoma cells $\left(\mathrm{IC}_{50}=\right.$ $9.8 \pm 0.82 \mu \mathrm{M})$, and even more toxic than the doxorubicin $\left(\mathrm{IC}_{50}=21.0 \pm 1.64 \mu \mathrm{M}\right)$ that is considered to be a "golden standard" in the anticancer chemotherapy (Fig. 3).

The general pattern of the cytotoxic activity of 5a-d thiazoles and doxorubicin towards human melanoma cells of WM793 line was similar to that described above for human glioblastoma U251 cells. $\mathrm{IC}_{50}$ for $5 \mathrm{c}$ was $32.3 \pm 2.15 \mu \mathrm{M}, \mathrm{IC}_{50}$ for $5 \mathrm{~d}$ was $34.6 \pm 2.24 \mu \mathrm{M}$,

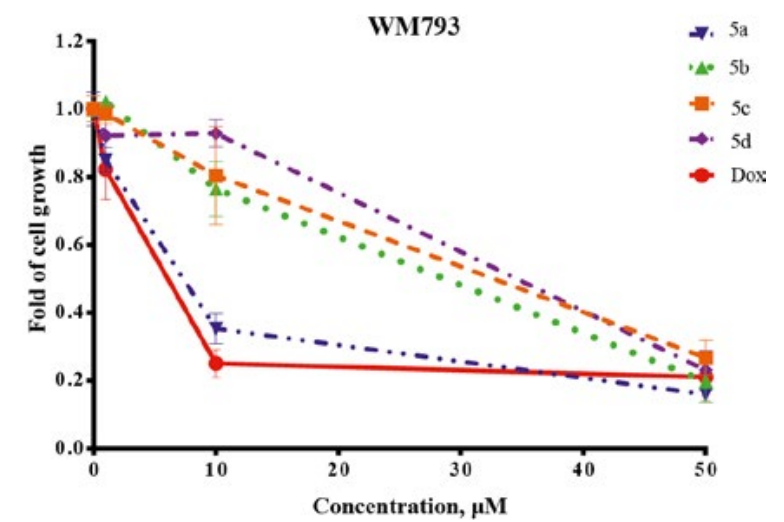

Fig. 3. Characteristics of cytotoxicity of thiazole derivatives $(5 a-d)$ and doxorubicin (Dox) towards human glioblastoma U251 cells and human melanoma WM793 cells. 

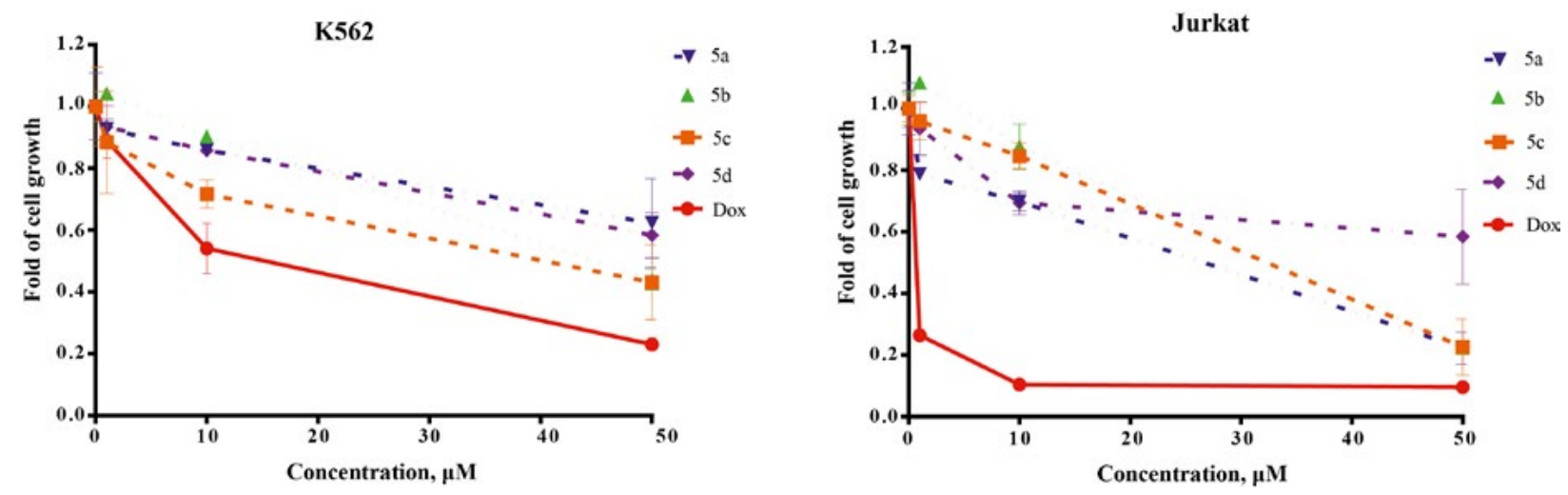

Fig. 4. Characteristics of cytotoxicity of thiazole derivatives (5a-d) and doxorubicin (Dox) towards human myeloid leukemia cells of K562 line and human acute T-cell leukemia cells of Jurkat line.

and $\mathrm{IC}_{50}$ for $5 \mathrm{~b}$ was $28.5 \pm 2.06 \mu \mathrm{M}$, whereas the 5 a compound was highly toxic for the melanoma cells $\left(\mathrm{IC}_{50}=7.2 \pm 0.48 \mu \mathrm{M}\right)$, and the toxicity of doxorubicin was similar to such effect of the 5 a compound $\left(\mathrm{IC}_{50}=6.1 \pm 0.38 \mu \mathrm{M}\right)$ (Fig. 3).

As four human tumor cell lines used above belong to the substrate-dependent type of cells, it was reasonable to study the effect of $5 \mathrm{a}-\mathrm{d}$ thiazoles and doxorubicin on the inhibition of growth of the leukemia cells in suspension. Thus, human myeloid leukemia cells of K562 line and human acute T-cell leukemia cells of Jurkat line were treated in vitro with the doxorubicin and experimental anticancer agents. We have found that $5 \mathrm{c}$ and $5 \mathrm{~b}$ compounds possessed a moderate toxicity for leukemia $\mathrm{K}-562$ cells $\left(\mathrm{IC}_{50}\right.$ for $5 \mathrm{c}$ was $40.0 \pm 2.65 \mu \mathrm{M}$ and $\mathrm{IC}_{50}$ for $5 \mathrm{~b}$ was $\left.44.7 \pm 3.15 \mu \mathrm{M}\right) .5 \mathrm{~d}$ and $5 \mathrm{a}$ compounds were relatively non-toxic for the leukemia K-562 cells in the concentration up to $50 \mu \mathrm{M}$ (Fig. 4), whereas the toxicity of doxorubicin was much higher comparing to the effect of thiazoles and $\mathrm{IC}_{50}$ for doxorubicin was $15.2 \pm 1.14 \mu \mathrm{M}$.
It was found that $5 \mathrm{c}, 5 \mathrm{a}$ and $5 \mathrm{~b}$ did not demonstrate significant toxicity for human acute T-cell leukemia cells of Jurkat line $\left(\mathrm{IC}_{50}\right.$ for $5 \mathrm{a}$ was $27.0 \pm 2.13 \mu \mathrm{M}, \mathrm{IC}_{50}$ for $5 \mathrm{c}$ was $32.3 \pm 2.73 \mu \mathrm{M}$, and $\mathrm{IC}_{50}$ for $5 \mathrm{~b}$ was $33.0 \pm 2.85 \mu \mathrm{M}$ ). The $5 \mathrm{~d}$ was poorly active towards the Jurkat leukemia cells in dose to $50 \mu \mathrm{M}$, whereas the doxorubicin was extremely toxic for these cells $\left(\mathrm{IC}_{50}=\right.$ $0.7 \pm 0.05 \mu \mathrm{M})($ Fig. 4).

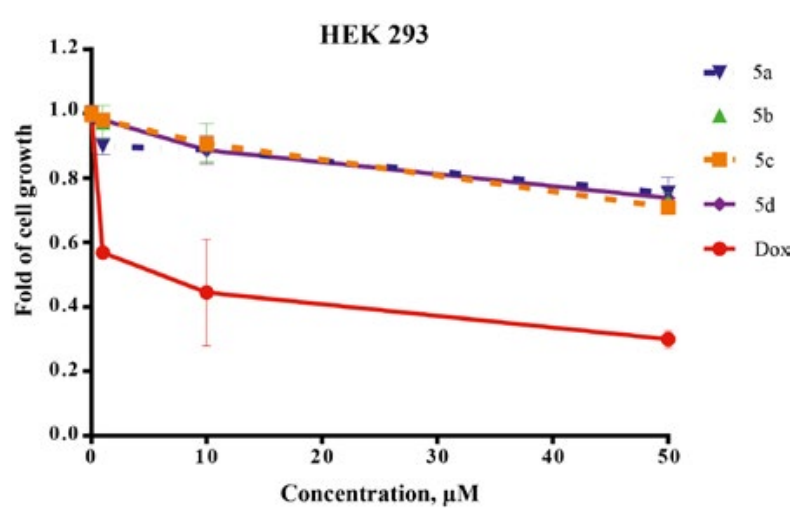

Fig. 5. Characteristics of cytotoxicity of thiazole derivatives (5a-d) and doxorubicin (Dox) towards human embryonic kidney cells of HEK 293 line. 
Thus, the tested thiazole derivatives showed a broad spectrum of the growth inhibition activity against human tumor cells of different tissue origin and the melanoma and glioma cells appeared to be more sensitive to the action of these derivatives comparing to human leukemia cells.

Finally, we have studied the cytotoxic effect of the novel thiazoles towards non-tumor pseudo-normal cells - human embryonic kidney cells of HEK293 line (Fig. 5). Notably, these cells demonstrated the resistance to the cytotoxic action of the thiazoles in dose up to $50 \mu \mathrm{M}$, whereas doxorubicin showed significant cytotoxicity with the IC50 $=\sim 20 \mu \mathrm{M}$.

\section{Discussion}

The tumor targeting technologies are focused on creating novel agents that effectively inhibit, reverse or delay carcinogenesis [27] through selective affecting tumor cells mostly by impairing their antioxidant potential [28] or inducing apoptosis [29, 30]. Additionally, the potential drugs should combat tumor cells of the advanced stages of malignancy (metastasis) that is a major cause of patients' mortality [1].

We have screened the anti-proliferative activity of the novel synthesized thiazoles $5 \mathrm{a}-\mathrm{d}$ towards human tumor cells of various tissue origin. The MTT assay-based evaluation of the survival of treated human breast adenocarcinoma cells of MCF-7 line and human lung adenocarcinoma cells of A549 line showed that these cells were sensitive to the cytotoxic action of the thiazoles used only in high doses (up to $50 \mu \mathrm{M}$ ). At the same time, these compounds possessed a distinct antineoplastic activity towards the human glioblastoma cells of
U251 line and human melanoma cells of WM793 line, whereas the human myeloid leukemia cells of K562 line and human acute T-cell leukemia cells of Jurkat line were less sensitive to the cytotoxic action of the experimental anticancer agents. The ranking of the toxic action of thiazoles and doxorubicin towards the glioblastoma U251 cells was as following: $5 \mathrm{a}>$ doxorubicin $>5 \mathrm{~d}>5 \mathrm{c} \approx 5 \mathrm{~b}$. $\mathrm{IC}_{50}$ of $5 \mathrm{a}$ for the glioblastoma cells equaled $9.8 \pm 0.82 \mu \mathrm{M}$, whereas doxorubicin was less toxic for these cells $\left(\mathrm{IC}_{50}=21.0 \pm 1.64 \mu \mathrm{M}\right)$. Obviously, the amides endowed with the benzofuran moiety (5a) possess a higher anticancer activity [31,32]. Glass et al. (2000) showed an inhibition of growth in human glioblastoma cell lines by the farnesyltransferase inhibitor SCH66336. However, the concentration of that inhibitor, which is required to achieve $50 \%$ inhibition $\left(\mathrm{IC}_{50}\right)$ ranged from $30 \mu \mathrm{M}$ (single $24 \mathrm{~h}$ treatment) to $10 \mu \mathrm{M}$ (5 day treatment). This is a higher dose compared to the dose required for distinct effect of $5 \mathrm{a}$ used in our study.

Malignant melanoma is a disease with a high mortality rate caused by rapid metastasis. Ciołczyk-Wierzbicka et al. [35] showed the inhibition of proliferation of human melanoma cells by using specific siRNA for silencing the $\mathrm{N}$-cadherin gene. Its silencing arrests the cell growth at the G1-phase of cell cycle and inhibits the cell entry into the S-phase. Noteworthy, there are no effective chemotherapies for the melanoma treatment [33]. The immunomodulating approaches used in clinics are still very costly and possess high general toxicity [34].

During studying the anti-proliferative activity of the synthesized thiazoles towards the 
human melanoma WM793 cells, we have found that $5 \mathrm{a}$ was also the most cytotoxic agent $\left(\mathrm{IC}_{50}=7.2 \pm 0.48 \mu \mathrm{M}\right)$ the action of which was comparable with the action of doxorubicin $\left(\mathrm{IC}_{50}=6.1 \pm 0.38 \mu \mathrm{M}\right)$. The toxicity rank of thiazoles and doxorubicin for the melanoma WM793 cells was: doxorubicin $\approx 5 \mathrm{a}>5 \mathrm{~b}>$ $5 \mathrm{c}>5 \mathrm{~d}$.

The synthesized thiazoles were also found to be toxic for leukemia cells - the human myeloid leukemia cells of K562 line and the human acute T-cell leukemia cells of Jurkat line, however, demonstrated their cytotoxicity only at high doses. The ranking of the toxic action of thiazoles and doxorubicin on the leukemia K562 cells was the following: doxorubicin $(15.2 \pm 1.14 \mu \mathrm{M})>5 \mathrm{c}(40.0 \pm 2.65 \mu \mathrm{M})$ $>5 \mathrm{~b}>5 \mathrm{~d}>5 \mathrm{a}$. Thus, the rank of toxicity of the 5a for these leukemia cells growing only in suspension is opposite to the rank found for the glioblastoma and melanoma cells growing in the monolayer culture. Thus, the role of silencing $\mathrm{N}$-cadherin (participates in cell attachment) for the inhibition of melanoma cells should be reminded here [35]. Doxorubicin was the most effective inhibitor of growth of the human acute T-cell leukemia cells of Jurkat line, and the rank of inhibitory effects dropped in the following manner: doxorubicin $\left(\mathrm{IC}_{50}=\right.$ $0.7 \pm 0.05 \mu \mathrm{M})>5 \mathrm{a}\left(\mathrm{IC}_{50}=27.0 \pm 2.13 \mu \mathrm{M}\right)>$ $5 c>5 b>5 d$. Obviously, amides 5 endowed with benzofuran moiety (5a) have a higher anticancer activity $[31,32]$.

It was also shown that thiazoles were not toxic for human embryonic kidney HEK293 cells, while doxorubicin had high cytotoxity towards these cells $\left(\mathrm{IC}_{50}\right.$ was $\left.5.7 \pm 0.42 \mu \mathrm{M}\right)$.

The tested thiazole derivatives showed a broad spectrum of the anti-proliferative acti- vity against human tumor cells of different tissue origin and the melanoma and glioma cells appeared to be more sensitive to the action of these derivatives comparing to human leukemia cells.

\section{Conclusion}

Four novel thiazole derivatives were synthesized and screened for their anticancer activity in vitro. These derivatives selectively inhibited the growth of human tumor cells, and 5a was the most potent agent demonstrating a selective action towards the glioma and melanoma cells, comparing to the leukemia cells. Thus, the thiazole derivatives are a perspective source of the innovative anticancer agents.

\section{Acknowledgments}

The authors thank Dr. O. Stasyk (Institute of Cell Biology, National Academy of Sciences of Ukraine, Lviv, Ukraine) for providing human melanoma cells of WM793 line. This work was partially financed by the grant № 0116U001533 from the Ukrainian government.

\section{REFERENCES}

1. Narang AS, Desai DS. Anticancer Drug Development. Unique Aspects of Pharmaceutical Development. Pharmaceutical Perspectives of Cancer Therapeutics. Ed. by Y. Lu, R.I. Mahato. Springer Science Business Media, LLC 2009:49-92.

2. Naveen Kumar D, Shikha S, Cijo George V, Suresh P, Ashok Kumar R. Anticancer and anti-metastatic activities of RHEUMEMODI rhizome chloroform extracts. Asian J Pharm Clin Res. 2012; 5(3):189-94.

3. Perry M, Doll DC, Freter CE. The Chemotherapy Source Book. - Philadelphia: WaltersKluwer. Lippincott Williams \& Wilkins, 2012; 248 p. 
4. Kobylinska LI, Havrylyuk DY, Ryabtseva AO, Mitina NE, Zaichenko OS, Lesyk RB, Zimenkovsky BS, Stoika RS. Biochemical indicators of hepatotoxicity in blood serum of rats under the effect of novel 4-thiazolidinone derivatives and doxorubicin and their complexes with polyethyleneglycol-containing nanoscale polymeric carrier. $U k r$ Biochem $J$. 2015;87(2):122-32.

5. Dos Santos TA, da Silva AC, Silva EB, Gomes PA, Espíndola JW, Cardoso MV, Moreira DR, Leite AC, Pereira $V R$. Antitumor and immunomodulatory activities of thiosemicarbazones and 1,3-Thiazoles in Jurkat and HT-29 cells. Biomed Pharmacother. 2016;82:555-60.

6. Ulusoy N, Kiraz M, Kucukbasmaci O. New 6-(4-Bromophenyl)-imidazo[2,1-b]thiazole Derivatives: Synthesis and Antimicrobial Activity. Monats Chem. 2002; 133(10):1305-5.

7. Al-Saadi MS, Faidallah HM, Rostom SA. Synthesis and biological evaluation of some 2,4,5-trisubstituted thiazole derivatives as potential antimicrobial and anticancer agents. Arch Pharm (Weinheim). 2008;341(7):424-34.

8. Karpov K, Nazarenko A, Pekarevskii B, Potekhin V. Biocidal and anticorrosive effect of 2-aminothiazole derivatives used as additives to jet fuels. Russ J Appl Chem. 2001; 74(6):998-1001.

9. Rehse K, Baselt T. New 2-amino-thiazole-4-acetamides with antiplatelet activity. Arch Pharm (Weinheim). 2008;341(10):645-54.

10. Karade HN, Acharya BN, Sathe M, Kaushik MP. Design, synthesis, and antimalarial evaluation of thiazole-derived amino acids Med Chem Res. 2008, 17(1):19-29.

11. Hassan GS, El-Messery SM, Al-Omary FA, ElSubbagh HI. Substituted thiazoles VII. Synthesis and antitumor activity of certain 2-(substituted amino)-4-phenyl-1,3-thiazole analogs. Bioorg Med Chem Lett. 2012;22(20):6318-23.

12. Li Z, Yang Q, Qian X. Novel thiazonaphthalimides as efficient antitumor and DNA photocleaving agents: effects of intercalation, side chains, and substituent groups. Bioorg Med Chem. 2005;13(16): 4864-70.
13. Ahn JH, Kim SJ, Park WS, Cho SY, Ha JD, Kim SS, Kang SK, Jeong DG, Jung SK, Lee SH, Kim HM, Park SK, Lee KH, Lee CW, Ryu SE, Choi JK. Synthesis and biological evaluation of rhodanine derivatives as PRL-3 inhibitors. Bioorg Med Chem Lett. 2006;16(11):2996-9.

14. Park H, Jung SK, Jeong DG, Ryu SE, Kim SJ. Discovery of novel PRL-3 inhibitors based on the structure-based virtual screening. Bioorg Med Chem Lett. 2008;18(7):2250-5.

15. Geronikaki A, Eleftheriou P, Vicini P, Alam I, Dixit A, Saxena AK. 2-Thiazolylimino/heteroarylimino-5-arylidene-4-thiazolidinones as new agents with SHP-2 inhibitory action. $J$ Med Chem. 2008;51(17): 5221-8.

16. Cutshall NS, O'Day C, Prezhdo M. Rhodanine derivatives as inhibitors of JSP-1. Bioorg Med Chem Lett. 2005;15(14):3374-9.

17. Carter PH, Scherle PA, Muckelbauer JK, Voss ME, Liu RQ, Thompson LA, Tebben AJ, Solomon KA, Lo YC, Li Z, Strzemienski P, Yang G, Falahatpisheh $N, X u M, W u Z$, Farrow NA, Ramnarayan $K$, Wang J, Rideout D, Yalamoori V, Domaille P, Underwood DJ, Trzaskos JM, Friedman SM, Newton $R C$, Decicco $C P$. Photochemically enhanced binding of small molecules to the tumor necrosis factor receptor-1 inhibits the binding of TNF-alpha. Proc Natl Acad Sci U S A. 2001;98(21):11879-84.

18. Degterev A, Lugovskoy A, Cardone M, Mulley B, Wagner $G$, Mitchison T, Yuan J. Identification of small-molecule inhibitors of interaction between the BH3 domain and Bcl-xL. Nat Cell Biol. 2001;3(2): 173-82.

19. Dayam R, Aiello F, Deng J, Wu Y, Garofalo A, Chen $X$, Neamati $N$. Discovery of small molecule integrin $\alpha v \beta 3$ antagonists as novel anticancer agents. J Med Chem. 2006; 49(15):4526-34.

20. Kok SH, Gambari R, Chui CH, Yuen MC, Lin E, Wong RS, Lau FY, Cheng GY, Lam WS, Chan SH, Lam KH, Cheng CH, Lai PB, Yu MW, Cheung F, Tang JC, Chan AS. Synthesis and anti-cancer activity of benzothiazole containing phthalimide on human carcinoma cell lines. Bioorg Med Chem. 2008;16(7):3626-31. 
21. Wang X, Sarris K, Kage K, Zhang D, Brown SP, Kolasa T, Surowy C, El Kouhen OF, Muchmore SW, Brioni JD, Stewart AO. Synthesis and evaluation of benzothiazole-based analogues as novel, potent, and selective fatty acid amide hydrolase inhibitors. J Med Chem. 2009;52(1):170-80.

22. Obushak N, Matiichuk V, Ganushchak N. Heterocyclic Syntheses on the Basis of Anionarylation Products of Unsaturated Compounds. I. 2-Amino-5arylmethyl-1,3-thiazoles. Russ J Org Chem. 1997; 33(7):1010-3.

23. Obushak N, Matiichuk V, Vasylyshin R, Ostapyuk Y. Heterocyclic syntheses on the basis of arylation products of unsaturated compounds: X. 3-Aryl2-chloropropanals as reagents for the synthesis of 2-amino-1,3-thiazole derivatives. Russ J Org Chem. 2004; 40(3):383-9.

24. Ostapiuk YV, Obushak MD, Matiychuk VS, Naskrent $M$, Gzella $A K$. A convenient method for the synthesis of 2-[(5-benzyl-1,3-thiazol-2-yl) imino]-1,3-thiazolidin-4-one derivatives. Tetrahedron Lett. 2012; 53(5):543-5.

25. Matiychuk VS, Obushak ND, Pidlypnyi NI, Ostapiuk YuV, Voloshchuk RM. Synthesis of heterocycles on the basis of products of arylation of unsaturated compounds. 22. 3-Aryl-2-chloropropanals in the synthesis of N-aryl-5-(R-benzyl)-1,3-thiazole2-amines. Chem Heterocycl Compd. 2010; 46(4):495-9.

26. Liu X, Zu Y, Fu Y, Yao L, Gu C, Wang W, Efferth T. Antimicrobial activity and cytotoxicity towards cancer cells of Melaleuca alternifolia (tea tree) oil. Eur Food Res Technol. 2009; 229:247-53.

27. Banerjee S, Panda CK, Das S. Clove (Syzygium aromaticum L.), a potential chemopreventive agent for lung cancer. Carcinogenesis. 2006;27(8):164554.

28. Khan N, Afaq F, Mukhtar H. Cancer chemoprevention through dietary antioxidants: progress and promise. Antioxid Redox Signal. 2008;10(3):475510. Reiew.

29. Paliwal S, Sundaram J, Mitragotri S. Induction of cancer-specific cytotoxicity towards human prostate and skin cells using quercetin and ultrasound. $\mathrm{Br} J$ Cancer. 2005;92(3):499-502.
30. Chen ZP, Schell JB, Ho CT, Chen KY. Green tea epigallocatechin gallate shows a pronounced growth inhibitory effect on cancerous cells but not on their normal counterparts. Cancer Lett. 1998;129(2):173-9.

31. Choi MJ, Jung KH, Kim D, Lee H, Zheng HM, Park BH, Hong SW, Kim MH, Hong S, Hong SS. Anticancer effects of a novel compound HS-113 on cell growth, apoptosis, and angiogenesis in human hepatocellular carcinoma cells. Cancer Lett. 2011; 306(2):190-6.

32. Choi MJ, Lee H, Lee JH, Jung KH, Kim D, Hong $S$, Hong SS. The effect of HS-111, a novel thiazolamine derivative, on apoptosis and angiogenesis of hepatocellular carcinoma cells. Arch Pharm Res. 2012;35(4):747-54.

33. Gray-Schopfer V, Wellbrock C, Marais R. Melanoma biology and new targeted therapy. Nature. 2007; 445(7130):851-7.

34. Couzin-Frankel J. Breakthrough of the year 2013. Cancer immunotherapy. Science. 2013;342(6165): 1432-3.

35. Ciołczyk-Wierzbicka D, Gil D, Laidler P. The inhibition of cell proliferation using silencing of $\mathrm{N}$-cadherin gene by siRNA process in human melanoma cell lines. Curr Med Chem. 2012;19(1): $145-51$.

\section{Антинеопластична активність нових похідних тіазолів}

Н. С. Фінюк, В. П. Гренюх, Ю. В. Остап’юк, В. С. Матійчук, Д. А. Фролов, М. Д. Обушак, Р. С. Стойка, А. М. Бабський

Створення нових ефективних субстанцій для використання у протипухлинній хіміотерапії $є$ актуальним напрямком медичної хімії. Мета. Дослідити цитотоксичну дію нових похідних тіазолу щодо пухлинних клітин різного тканинного походження. Методи. Чотири нові $\mathrm{N}$-ацильованих 2-аміно-5-бензил-1,3-тіазолів (субстанції 5a-d) були синтезовані взаємодією 2-аміно5-R-бензил-1,3-тіазолів з ацилхлоридами у середовищі діоксану за наявності триетиламіну. Для дослідження протипухлинної активності похідних тіазолу використовували МТТ-тест. Результати. Встановлено, що 
деякі похідні тіазолу мають антинеопластичну активність щодо пухлинних клітин різного тканинного походження. Показано селективну антигліомну та антимеланомну дію досліджуваних сполук. Речовина 5а має найбільш виражену цитотоксичну дію щодо клітин лінії U251 гліобластоми людини і лінії WM793 меланоми людини. Синтезовані сполуки мають низьку токсичність щодо псевдонормальних ембріональних клітин нирки. Висновок. Нове похідне тіазолу (речовина 5а) є перспективним цитотоксичним чинником для дії на клітини гліобластоми і меланоми.

К л ю ч о в і с л о в а: похідні тіазолу, 2-аміно-5-бензил1,3-тіазоли, протипухлинна активність, лейкоз, гліобластома, меланома.

\section{Антинеопластическая активность новых производных тиазола}

Н. С. Финюк, В. П. Гренюх, Ю. В. Остапюк, В. С. Матийчук, Д. А. Фролов, М. Д. Обушак, Р. С. Стойка, А. М. Бабский

Разработка и синтез новых производных тиазола являются перспективным направлением медицинской химии и противоопухолевой терапии. Цель. Изучение цитотоксического действия новых производных тиа- зола в отношении злокачественных клеток различного тканевого происхождения. Методы. Четыре новых $\mathrm{N}$-ацилированных 2-амино-5-бензил-1,3-тиазола (5ad) были синтезированы взаимодействием 2-амино-5-R-бензил-1,3-тиазолов с ацилхлоридами в присутствии триэтиламина в среде диоксана. Исследование противоопухолевой активности тиазолов проводили с использованием МТТ-анализа. Результаты. Установлено, что производные тиазола оказывают противоопухолевое действие на некоторые типы опухолей. Было подтверждено селективное антиглиомное и антимеланомное действие соединений. Соединение 5а проявляет наиболее выраженное цитотоксическое действие на опухолевые клетки U251 глиобластомы человека и WM793 меланомы человека. Исследованные соединения обладают низкой токсичностью по отношению к псевдо-нормальным эмбриональным клеткам почек. Вывод. Соединение 5а является перспективным токсическим агентом для клеток глиобластомы и меланомы.

К л юч е в ы е с л о в а: производные тиазола, 2-амино5-бензил-1,3-тиазолы, противоопухолевая активность, лейкоз, глиобластома, меланома.

Received 10.03.2017 